\title{
ANT AND TERMITE MOUND COINHABITANTS IN THE WETLANDS OF SANTO ANTONIO DA PATRULHA, RIO GRANDE DO SUL, BRAZIL
}

\author{
DIEHL, E., ${ }^{1}$ JUNQUEIRA, L. K. ${ }^{2}$ and BERTI-FILHO, E. ${ }^{3}$ \\ ${ }^{1}$ Laboratório de Genética de Insetos Sociais, UNISINOS, C.P. 275 , \\ CEP 93001-970, São Leopoldo, RS, Brazil \\ ${ }^{2}$ Faculdade de Ciências Matemáticas, da Natureza e Tecnologia da Informação, \\ UNIMEP, Rod. do Açúcar, km 156, CEP 13400-911, Piracicaba, SP, Brazil \\ ${ }^{3}$ Departamento de Entomologia, Fitopatologia e Zoologia Agrícola, \\ ESALQ/USP, C.P. 9, CEP 13418-900, Piracicaba, SP, Brazil \\ Correspondence to: Elena Diehl, Laboratório de Genética de Insetos Sociais, UNISINOS, \\ C.P. 275, CEP 93001-970, São Leopoldo, RS, Brazil \\ Received May 27, 2003 - Accepted January 6, 2004 - Distributed August 31, 2005
}

(With 1 figure)

\begin{abstract}
This paper reports on ant and termite species inhabiting the mounds (murundus) found in three wetland sites in Santo Antonio da Patrulha. Ants and termites were found in $100 \%$ of the mounds of two sites and in $20 \%$ of those in the third site. Colonies of Camponotus fastigatus were found inhabiting all the mounds, while colonies of Brachymyrmex sp., Linepithema sp., Pheidole sp., and/or Solenopsis sp. were collected in less than $30 \%$ of the mounds. In the mounds of the three sites, colonies of Anoplotermes sp. and/or Aparatermes sp. termites were found together with the ant colonies. Another cohabiting termite species, Cortaritermes sp., was found only in the mounds of one site. The results suggest that $C$. fastigatus is the species building the mounds, with the other species, whether ants or termites, being the inquilines.
\end{abstract}

Key words: Insecta, Formicidae, Termitidae, ant-termite association.

\section{RESUMO}

\section{Formigas e térmitas co-habitantes dos murundus em zonas úmidas de Santo Antonio da Patrulha, Rio Grande do Sul, Brasil}

Neste trabalho são relatadas as espécies de formigas e de térmitas co-habitantes dos murundus em três áreas de zonas úmidas, no município de Santo Antônio da Patrulha, RS. Em todos os murundus foram encontradas colônias de formigas, sendo que Camponotus fastigatus ocorreu em 100\% deles e, em menos de 30\%, também havia colônias de Brachymyrmex sp., Linepithema sp., Pheidole sp. e/ou de Solenopsis sp. Co-habitando com as formigas, nos murundus das três áreas, foram encontradas colônias dos térmitas Anoplotermes sp. e/ou de Aparatermes sp. Uma terceira espécie de térmita cohabitante, Cortaritermes sp., foi encontrada apenas nos murundus de uma das áreas. Os dados obtidos sugerem que $C$. fastigatus seria a espécie construtora dos murundus e as demais espécies de formigas e de térmitas seriam inquilinas.

Palavras-chave: Insecta, Formicidae, Termitidae, associação formigas-térmitas. 


\section{INTRODUCTION}

The relationship between ants and termites has been considered as either comensal or parasitic, with the ants the only beneficiaries, using the termite mounds to nest and/or obtain food (Deligne et al., 1981; Dejean \& Bolton, 1995; Dejean et al., 1997; Dejean \& Féneron, 1999; Leponce et al., 1999). However, other authors claim that ants are the most significant enemies of termites (Brian, 1983; Hölldobler \& Wilson, 1990; Cornelius \& Grace, 1994a, 1994b, 1996; Cornelius et al., 1995). In addition, Higashi \& Ito (1989) and Jaffé et al. (1995) for the first time presented indications that some ant species coinhabiting in termite nests provide protection against predator attacks, thus characterizing a mutualistic relationship. On the other hand, registers of termites living inside ant nests, such as that of Crist \& Friese (1994) are very rare.

In the wetlands near the northern coast of Rio Grande do Sul State, physiographically distinct sites present a number of mounds that are covered almost to the top with gramineous plants. These mounds, called murundus by local inhabitants, are quite different from those found in the cerrado of the Brazilian west-central region (Diniz de Araujo Neto et al., 1986).

In Rio Grande do Sul State, some wetlands are used for rice paddies, which after one or two harvests are abandoned and subsequently used as natural pasture for cattle. After two or three years without tillage, small mounds appear that are inhabited by gradually increasing numbers of termites and/or ant populations. These mounds are an ordinary part of the landscape, and the species of these ants and termites is normally unknown. To remedy this situation, the work reported on in this paper was carried out to compare the mounds of three wetland sites with respect to mound size, number and distribution per hectare, as well as the cohabiting ant and termite species collected.

\section{MATERIAL AND METHODS}

The insects were collected from June 2000 to February 2001 in three wetland sites located in the municipality of Santo Antonio da Patrulha, Rio Grande do Sul State, Brazil. Site 1 (2954'24.2's; 50'33'37.0”'W) and 3 (2954'15.4”S; 50'33'36.9'W) are close together and 1,000 meters apart from site 2 (2953'09.3'S; 50³2'57.2'W). Sites, 1, 2, and 3 have not been cultivated for 10,25 , and 2 years, respectively, being used as pasture for cattle. They present grassy vegetation, with many Baccharis (Asteraceae) shrubs and Iheringia (Umbellifereae). Site 2 presents a well-developed vegetation as well as a number of already decomposing fallen bushes and trees.

To estimate the number of mounds per hectare, transects $(100 \mathrm{~m}$ long $\times 5 \mathrm{~m}$ wide) were fixed so as to sample $10 \%$ of each site. Thus, ten transects were drawn in site 1 ( 5 ha), five in site 2 (2.5 ha), and six in site 3 ( 3 ha). All mounds along the transects were counted.

Three (site I) and five (site II) 100-square meter plots were delimited to measure the distance between the mounds and estimate the mean spacing separating them. Spacing among mounds of site 3 was only visually evaluated.

The largest and smallest diameters and the greatest height of 58 mounds in site 1 and 50 mounds in site 2 were measured. In site 3, only the heights of 25 mounds were measured. For each variable the mean and standard error were estimated. To compare the data obtained from the three sites, the qui-square test was used.

Ants and termites were collected from the top, middle, and bottom parts of excavated site- 1 mounds (35) as well as site- 2 mounds (30). Because the mounds of site 3 were so small, they were opened completely for termite ant collection. The termite species were identified by using the dichotomous keys of Fontes (1983) and Constantino (1999); specimens were deposited in the Isoptera Colletion of the Laboratory of Forest Entomology, the Luiz de Queiroz College of Agriculture, University of São Paulo, and in the Isoptera Collection of the Laboratory of Social Insect Genetics (Vale do Rio dos Sinos University), in which, before specimens were deposited, the morphospecies were separated according to laboratory patterns. The ants were identified according to Bolton (1994).

For each site the richness of ants and termites was calculated by adding the species found in the mounds evaluated. The frequency of each species was calculated by the number of mounds in which the species were found, divided by the number of sampled mounds. 


\section{RESULTS AND DISCUSSION}

The highest density of mounds per hectare was found in site 1 , which was more than double of that in site 2, and 11 times higher than that of site 3 (Table $1)$; these differences were significant $\left(X^{2}=1070.617\right.$; d.f. $=2 ; \mathrm{p}>0.001)$. For site 3, visual evaluation indicated a minimal distance of ca. five meters, with a maximum of about eight meters between mounds. Although the mounds of site 1 showed shorter basal diameter, largest apical diameter, and mean height slightly higher than those of site 2 (Table 1), the differences were not significant.

One should suggest that the differences of size and density of the mounds observed at all sites could be due to the time period elapsed since these areas were no longer being cultivated. Thus, for site 3, with no tillage for a two-year period, the reduced size and low density of mounds per hectare would indicate the initial stage of mound buildup. The passage of time results in increased size and height of the mounds, due to growing soil input. New development increases the density among mounds per hectare, thus diminishing space between them. Conversely, mound destruction reduces density and increases the distance among them. Pomeroy (1989) affirmed that many parameters influence the location and dispersion of termite colonies. Thus, for species nesting in clay soils in flooding periods, rising waters may kill the queen or newly-formed colonies, or even destroy the nest. Microhabitat variations, such as those created by the edging effects, gaps in vegetation, and empty nest occurrence, are also important. According to the author previously cited, empty nests, for instance, should be preferred by other termites for establishing new colonies..

Based on the ant species nesting in them, the mounds studied were designed as mono- or polyspecific (Table 2). Camponotus fastigatus (Formicinae) was the only ant species found in all mounds from each of the three sites, and is thus the dominant species in this area. Other ant colonies found, but at low frequency of occurrence, were: Brachymyrmex sp. (Formicinae), Linepithema sp. (Dolichoderinae), and/or Pheidole sp. (Myrmicinae) (Table 3), all of which are considered opportunistic.

Of the 30 mounds evaluated in site 2, 20 $(67.0 \%)$ showed excavations running from the bottom up to the beginning of the top portion. In $19(95.0 \%)$ of these mounds, colonies of Acromyrmex heyeri (Myrmicinae, Attini) were found. As for site 1 , the few $A$. heyeri nests observed $(\mathrm{N}=12)$ were found externally at the bottom of the mounds. The occurrence of such nests is fairly common at the bottom of termite nests, tree trunks, posts, or under logs or rocks (Diehl-Fleig \& Droste, 1992), or even inside abandoned termite nests. However, this is the first record of this leaf-cutting ant species cohabiting with other ant species and termites.

TABLE 1

Characterization of mounds from three wetland sites in the municipality of Santo Antonio da Patrulha, State of Rio Grande do Sul, Brazil.

\begin{tabular}{|l|c|c|c|}
\hline \multirow{2}{*}{ Measures } & \multicolumn{3}{c|}{ Sites } \\
\cline { 2 - 4 } & $\mathbf{1}$ & $\mathbf{2}$ & $\mathbf{3}$ \\
\hline Density of mounds/hectare & 1.274 & 536 & 116 \\
\hline Distance (m) (min. \& max.) among mounds & $0.50-2.10$ & $0.50-12.0$ & $>5.00-<8.00$ \\
\hline Mean distance (m) among mounds & $0.95(0.28)$ & $3.86(0.89)$ & NE \\
\hline Mean height (m) (+ - s.e) & $0.56(0.13)$ & $0.53(0.14)$ & $0.20(0.05)$ \\
\hline Highest mean diameter $(\mathrm{m})(+-$ s.e. $)$ & $0.86(0.12)$ & $1.00(0.29)$ & $\mathrm{NE}$ \\
\hline Lowest mean diameter $(\mathrm{m})(+-$ s.e. $)$ & $0.40(0.07)$ & $0.29(0.10)$ & $\mathrm{NE}$ \\
\hline NE. not evaluated & & & \\
\hline
\end{tabular}


The mounds were also classified as mono- and polyspecific, according to the termite species inhabiting them (Table 4). Thus, in sites 1 and 3, mounds of Anoplotermes sp. and/or Aparatermes sp., both species of the subfamily Apicotermitinae, were found. In site 2, where mono- and polyspecific mounds were also observed, in addition to these two species of Apicotermitinae, a species of the genus Cortaritermes (Nasutitermitinae) was found.

In sites 1 and 2, most of the mounds had two or three termite species while those with only one were rather rare. As for site 1, Anoplotermes sp. and Aparatermes sp. were both numerous, whereas in site 2 they represented, respectively, the highest and lowest quantities found (Table 5). Finally, at site 3 termites were found in only six $(20.0 \%)$ of the 30 evaluated mounds.

Domingos \& Gontijo (1996), working in cerrado areas, verified that $63.0 \%$ of the termite nests were epigeous and monospecific, while the others were polyspecific, having two to fourteen termite species. The authors suggested that the association among the species might be related to the type of defense (chemical and/or mechanical) as well as to nest-building ability. A well-developed defense system would increase the chances of living in monospecific nests. On the other hand, the greater or lesser durability of the nests, coupled with the features and density of each of the other termite species living in the area, would also affect cohabitation probability.

Among the termite species found in the wetlands of Santo Antonio da Patrulha, Cortaritermes sp. alone has soldiers equipped for chemical defense. This species was only found sharing nests with the Apicotermitinae, which do not have soldiers. The fact that this Nasutitermitinae occurred only in the site 2 mounds that appeared to be the oldest ones suggests that of the three termite species, Cortaritermes sp. with its soldiers and chemical defenses would be the last to cohabit in previously existing nests.

According to Eggleton et al. (1995), no estimation exists of the ecological impact of Apicotermitinae, nor do data on the nutritional requirements, number, or biomass of its species. Constantino (1999) affirmed that the genus Anoplotermes is found in all Brazilian regions, in the most diverse habitats, and most of its species live in diffused galleries in the soil and feed on decomposing organic matter, with some species building epigeous nests, and others building arboreous ones.

TABLE 2

Occurrence of mounds with one or more ant species in three wetland sites in the municipality of Santo Antonio da Patrulha, State of Rio Grande do Sul, Brazil.

\begin{tabular}{|c|c|c|c|c|c|c|c|}
\hline \multirow{3}{*}{ Mounds } & \multirow{3}{*}{ Ant species } & \multicolumn{6}{|c|}{ Sites } \\
\hline & & \multicolumn{2}{|c|}{1} & \multicolumn{2}{|c|}{2} & \multicolumn{2}{|c|}{3} \\
\hline & & $\mathbf{N}$ & $\%$ & $\mathbf{N}$ & $\%$ & $\mathbf{N}$ & $\%$ \\
\hline \multirow{5}{*}{ Polyspecific } & $\begin{array}{c}\text { C. fastigatus } \\
+ \text { Brachymyrmex sp. } \\
+ \text { Solenopsis } \mathrm{sp} .\end{array}$ & 3 & 8.5 & 1 & 3.3 & 1 & 3.3 \\
\hline & $\begin{array}{c}\text { C. fastigatus } \\
+ \text { Brachymyrmex sp. }\end{array}$ & 5 & 14.3 & 1 & 3.3 & 1 & 3.3 \\
\hline & $\begin{aligned} & \text { C. fastigatus } \\
+ & \text { Solenopsis sp. }\end{aligned}$ & 0 & - & 0 & - & 2 & 6.7 \\
\hline & $\begin{array}{l}\text { C. fastigatus } \\
+ \text { Pheidole sp. }\end{array}$ & 1 & 2.9 & 1 & 3.3 & 0 & - \\
\hline & $\begin{array}{c}\text { C. fastigatus } \\
+ \text { Linepithema sp. }\end{array}$ & 0 & - & 2 & 6.7 & 0 & - \\
\hline Monospecific & C. fastigatus & 26 & 74.3 & 25 & 83.4 & 26 & 86.7 \\
\hline \multicolumn{2}{|c|}{ Total } & 35 & 100.0 & 30 & 100.0 & 30 & 100.0 \\
\hline
\end{tabular}


TABLE 3

Frequency of occurrence $(\%)$ of ant species found in the mounds of three wetland sites in the municipality of Santo Antonio da Patrulha, Rio Grande do Sul State, Brazil.

\begin{tabular}{|c|c|c|c|c|}
\hline \multirow{2}{*}{ Subfamilies } & \multirow{2}{*}{ Species } & \multicolumn{3}{|c|}{ Sites } \\
\cline { 3 - 5 } & & $\mathbf{1}$ & $\mathbf{2}$ & $\mathbf{3}$ \\
& & $\mathbf{r = 4}$ & $\mathbf{r = 5}$ & $\mathbf{r}=\mathbf{3}$ \\
\hline \multirow{2}{*}{ Formicinae } & Camponotus fastigatus & 100.00 & 100.00 & 100.00 \\
\cline { 2 - 5 } & Brachymyrmex sp. & 22.86 & 6.67 & 6.67 \\
\hline \multirow{2}{*}{ Myrmicinae } & Solenopsis sp. & 5.71 & 3.33 & 10.00 \\
\cline { 2 - 5 } & Pheidole $\mathrm{sp}$. & 2.86 & 3.33 & 0 \\
\hline Dolichoderinae & Linepithema $\mathrm{sp}$. & 0 & 6.67 & 0 \\
\hline
\end{tabular}

$\mathrm{r}=$ richness.

TABLE 4

Relative abundance of mounds with one or more termite species in three wetland sites in the municipality of Santo Antonio da Patrulha, Rio Grande do Sul State, Brazil.

\begin{tabular}{|c|c|c|c|c|c|c|c|}
\hline \multirow{3}{*}{ Mounds } & \multirow{3}{*}{ Termite species } & \multicolumn{6}{|c|}{ Sites } \\
\hline & & \multicolumn{2}{|c|}{1} & \multicolumn{2}{|c|}{2} & \multicolumn{2}{|c|}{3} \\
\hline & & $\mathbf{N}$ & $\%$ & $\mathbf{N}$ & $\%$ & $\mathbf{N}$ & $\%$ \\
\hline \multirow{4}{*}{ Polyspecific } & $\begin{array}{l}\text { Anoplotermes sp. } \\
+ \text { Aparatermes sp. } \\
\text { Cortaritermes sp. }\end{array}$ & 0 & - & 4 & 13.3 & 0 & - \\
\hline & $\begin{array}{l}\text { Anoplotermes sp. } \\
+ \text { Aparatermes sp. }\end{array}$ & 32 & 91.4 & 4 & 13.3 & 2 & 33.3 \\
\hline & $\begin{array}{l}\text { Anoplotermes sp. } \\
+ \text { Cortaritermes sp. }\end{array}$ & 0 & 0 & 13 & 43.3 & 0 & - \\
\hline & $\begin{array}{l}\text { Aparatermes sp. } \\
+ \text { Cortaritermes sp. }\end{array}$ & 0 & - & 5 & 16.8 & 0 & - \\
\hline \multirow{3}{*}{ Monospecific } & Anoplotermes sp. & 2 & 5.7 & 4 & 13.3 & 0 & - \\
\hline & Aparatermes sp. & 1 & 2.9 & 0 & - & 4 & 66.7 \\
\hline & Cortaritermes sp. & 0 & - & 0 & - & 0 & - \\
\hline \multicolumn{2}{|c|}{ Total } & 35 & 100.0 & 30 & 100.0 & 6 & 100.0 \\
\hline
\end{tabular}

In contrast, little is known about the Aparatermes genus, of which up to now, only one species has been described, A. abbreviatus, in Argentina. But probably many undescribed species of this genus occur in Brazil.

The only described species of the genus Cortaritermes, $C$. silvestrii, is found in the wet areas of the cerrado region (Constantino, 1999). It feeds on gramineous roots or organic residue (Matthews, 1977), and builds a small, roundish, and relatively less resistant carton nest (Coles de Negret \& Redford, 1982). However, Cortaritermes sp. collected in the wetlands of Rio Grande do Sul State does not build carton nests, but selects the top of mounds without carton structures, suggesting that this is a species distinct from $C$. silvestrii. 
TABLE 5

Frequency of occurrence $(\%)$ of termite species found in the mounds of three wetland sites in the municipality of Santo Antonio da Patrulha, Rio Grande do Sul, State, Brazil.

\begin{tabular}{|c|c|c|c|c|}
\hline \multirow{2}{*}{ Subfamilies } & \multirow{2}{*}{ Species } & \multicolumn{3}{|c|}{ Sites } \\
\cline { 3 - 5 } & & $\mathbf{1}$ & $\mathbf{2}$ & $\mathbf{3}$ \\
& & $\mathbf{r = 2}$ & $\mathbf{r = 3}$ & $\mathbf{r = 2}$ \\
\hline \multirow{2}{*}{ Apicotermitinae } & Anoplotermes $\mathrm{sp}$. & 97.14 & 83.33 & 6.67 \\
\cline { 2 - 5 } & Aparatermes $\mathrm{sp}$. & 94.29 & 43.33 & 20.00 \\
\hline Nasutitermitinae & Cortaritermes $\mathrm{sp}$. & 0 & 73.33 & 0 \\
\hline
\end{tabular}

$\mathrm{r}=$ richness.

Dejean \& Bolton (1995) and Dejean et al. (1997), dealing with fauna found in the nests of Procubitermes niapunesis and Cubitermes subarquatus, observed that ants and other termite species were the most frequent insects, with the diversity of termite genera being lower than that of the ants. We observed that the ants outnumbered the termites in the mounds of Santo Antonio da Patrulha wetlands.

Reports on ants cohabiting termite nests are fairly common (Brian, 1983; Higashi \& Ito, 1989; Hölldobler \& Wilson, 1990; Martius, 1994; Leponce et al., 1999). However, references to termites inhabiting ant nests are quite rare, one of them being Crist \& Friese's (1994) who observed a species of subterranean termite, Reticulitermes tibialis, in two arid ecosystems, living in nests of Pogonomyrmex occidentalis, when this ant reduces its activity in autumn.

Ants and termites were found in $100 \%$ of the mounds from sites 1 and 2 . In site 3, where apparently the mounds were in the first building stage, only $20 \%$ of the 30 evaluated nests contained cohabiting ants and termites. In the others, only $C$. fastigatus was found, thus suggesting that this ant species was the builder of the nest while the other species, either ants or termites, was the inquiline.

Acknowledgements - We thank Dr. Luiz Roberto Fontes for helping in identifying the termites; Eduardo Diehl-Fleig, Márcia Helena Bulsing, and Thaïs M. Hameister for field assistance; and Teresa Borges allowing us to work on her property. We are grateful to UNISINOS and the National Counsel of Technological and Scientific Development $(\mathrm{CNPq})$ for financial support.

\section{REFERENCES}

BOLTON, B., 1994, Identification guide to the ant genera of the world. Harvard University Press, Cambridge, MA, 222p.

BRIAN, M. V., 1983, Social Insects: ecology and behavioral biology. Chapman and Hall, London, 362p.

COLES DE NEGRET, H. R \& REDFORD, K. H., 1982, The biology of nine termite species (Isoptera: Termitidae) from the cerrado of Central Brazil. Psyche, 89: 81-106

CONSTANTINO, R., 1999, Chave ilustrada para identificação dos gêneros de cupins (Insecta: Isoptera) que ocorrem no Brasil. Papéis Avulsos de Zool., 40(25): 387-448.

CORNELIUS, M. L. \& GRACE, J. K., 1994a, Behavioral responses of the formosan subterranean termite (Isoptera: Rhinotermitidae) to semiochemicals of seven ant species. Env. Entomol., 23(6): 1524-1528.

CORNELIUS, M. L. \& GRACE, J. K., 1994b, Semiochemicals extracted from a dolichoderine ant affects the feeding and tunneling behavior of the Formosan subterranean termite (Isoptera: Rhinotermitidae). J. Econ. Entomol., 87(3): 705708.

CORNELIUS, M. L. \& GRACE, J. K., 1996, Effect of two ant species (Hymenoptera: Formicidae) on the foraging and survival of the formosan subterranean termite (Isoptera: Rhinotermitidae). Env. Entomol., 25(1): 85-89.

CORNELIUS, M. L., GRACE, J. K., FORD, P. W. \& DAVIDSON, B. S., 1995, Toxicity and repellency of semiochemicals extracted from a dolichoderine ant (Hymenoptera, Formicidae) to the formosan subterranean termite (Isoptera: Rhinotermitidae). Env. Entomol., 24(5): 1263-1269.

CRIST, T. O. \& FRIESE, C. F., 1994, The use of ant nests by subterranean termites in two semiarid ecosystems. Am. Midl. Nat., 131(2): 370-373.

DEJEAN, A. \& BOLTON, B., 1995, Fauna sheltered by Procubitermes niapuensis termitaries of the African rainforest. Journal of African Zoology, 109(5-6): 481-487. 
DEJEAN, A., BOLTON, B. \& DURAND, J. L., 1997, Cubitermes subarquatus termitaries as shelters for soil fauna in African rainforests. Journal of Natural History, 31(8): 1289-1302.

DEJEAN, A. \& FÉNÉRON, R., 1999, Predatory behavior in the ponerine ant, Centromyrmex bequaerti: a case of termitolesty. Behav. Processes, 47: 125-133.

DELIGNE, J., QUENNEDEY, A. \& BLUM, M. S., 1981, The enemies and defense mechanisms of termites, pp. 1-76. In: H. R. Hermann (ed.), Social Insects, $2^{\circ}$ vol. Academic Press, New York.

DIEHL-FLEIG, E. \& DROSTE, A., 1992, Localização, morfologia externa e flutuações populacionais ao longo do ano de colônias de Acromyrmex heyeri (Hymenoptera: Formicidae). An. Soc. Ent. Brasil., 21(1): 21-27.

DINIZ DE ARAUJO NETO, M., FURLEY, P. A., HARIDASAN, M. \& JOHNSON, C. E., 1986, The murundus of the cerrado region of Central Brazil. J. Trop. Ecol., 2: 17-35.

DOMINGOS, D. J. \& CONTIJO, T. A., 1996, Multi-occupation of termite mounds in cerrado vegetation in south-eastern Brazil. Rev. Bras. Biol., 56(4): 717-723.

EGGLETON, P., BIGNELL, D. E., SANDS, W. A., WAITE, B., WOOD, T. G. \& LAWTON, J. H., 1995, The species richness of termites (Isoptera) under differing levels of forest disturbance in the Mbalmayo Forest Reserve, southern Cameroon. J. Trop. Ecol., 11: 85-98.
FONTES, L. R., 1983, Acréscimos e correções ao "Catálogo dos Isoptera do Novo Mundo". Rev. Bras. Entomol., 17(2): 137-145.

HIGASHI, S. \& ITO, F., 1989, Defense of termitaria by termitophilous ants. Oecologia, 80: 147-147.

HÖLLDOBLER, B. \& WILSON, E. O., 1990, The Ants. Harvard University Press, Massachussets, 742p.

JAFFÉ, K., RAMOS, C. \& ISSA, S., 1995, Trophic interactions between ants and termites that share common nests. Ann. Entomol. Soc. Am., 88(3): 328-333.

LEPONCE, M., ROISIN, Y. \& PASTEELS, J. M., 1999, Community interations between ants and arboreal-nesting termites in New Guinea coconut plantations. Ins. Soc., 46(2): 126-130.

MARTIUS, C., 1994, Termite nests as structural elements of the Amazon floodplain forest. Andrias, 13: 137-150.

MATTHEWS, A. G. A., 1977, Studies on termite from the Mato Grosso State, Brazil. Academia Brasileira de Ciências, Rio de Janeiro, 267p.

POMEROY, D. E., 1989, Studies on a two species population of termites in Kenya (Isoptera). Sociobiology, 15: 219-236. 